\begin{tabular}{|c|c|}
\hline \multirow{2}{*}{ MAGNA } & Research Article \\
MEDIKA & Berkala Ilmiah Kedokteran dan Kesehatan \\
\cline { 2 - 2 } & Journal Page: https://jurnal.unimus.ac.id/index.php/APKKM
\end{tabular}

\title{
Effect on Dimensions of Health Services to Inpatients Satisfaction at Primary Health Care
}

\author{
Ayu Rahajeng Dianing Negari ${ }^{1}$, Annisa Nurida ${ }^{2}$, Musa Ghufron ${ }^{3}$, Muhammad Anas \\ 1,3,3,4) Medical Faculty, Universitas Muhammadiyah Surabaya
}

\begin{tabular}{l} 
Article Info \\
\hline Article history: \\
Received 23 December 2020 \\
Revised 30 July 2021 \\
Accepted 30 July 2021 \\
Available online 01 August \\
2021 \\
\hline Keywords: \\
Dimensions, service health, \\
community, satisfaction \\
\hline Correspondence: \\
muhanasjamil1@yahoo.co.id \\
\hline How to cite this article: \\
Ayu Rahajeng Dianing Negari, Annisa Nu- \\
rida, Musa Ghufron, Muhammad Anas. \\
Effect on Dimensions of Health Services \\
to Inpatients Satisfaction at Primary \\
Health Care. MAGNA MEDIKA Berk \\
Ilm Kedokt dan Kesehat. 2020;8(2):71-83
\end{tabular}

\begin{abstract}
Background: Satisfaction is a feeling that the consumers feel when the service they receive meets or surpass their expectations. Public satisfaction with health care services is still a significant issue for health institutions in improving the service quality. Despite various efforts that health care providers have made, some residents in an area were unsatisfied with the health services in their environment.
\end{abstract}

Objective: To determine the effect of the dimensions of health service quality on patient satisfaction at the Primary Health Care 1 Melaya, Jembrana, Bali

Method: Analytical observational study, a cross-sectional design. The total sample was 70 respondents. Data collection was performed using questionnaires. Multiple linear regression was used to analyze the average value of patient satisfaction based on the five dimensions of quality of health care.

Result: The dimensions of tangibility, responsiveness, assurance, and empathy have a significance value $(p<0.05)$, while the reliability dimension has no significance value $(\mathrm{p}>0.05)$. So the formula used to predict patient satisfaction with health services received is as follows:

$\mathrm{y}=0,352+0,295 * X 1-0,104 * X 2-0,201 * X 3+0,334 * X 4+0,180 * X 5$

The dimension of health services that has the largest influence on the satisfaction of inpatients is assurance. Patients feel assured and satisfied when the health workers communicate their expertise and competencies before doing their work.

Conclusion: Tangibility, reliability, responsiveness, and assurance were four of five dimensions of health services that have significantly influenced the satisfaction of inpatients. 


\section{INTRODUCTION}

Satisfaction is a feeling that consumers feel after getting satisfactory results from their performance ${ }^{1}$. According to Oliver, satisfaction is a person's feeling after comparing the performance and perceived results with what he expected $^{2}$. Community satisfaction with health services is still the main task for health agencies in improving service quality3. Sometimes it is subjective and can even be objective if many people have the same opinion on something ${ }^{3}$.

The patient's ideal quality pinned to the health agency will appear when the patient's expectations for the service have been met. The definition of quality expressed by Tjiptono is an effort made to realize consumer desires. Conversely, for patients who do not feel service satisfaction or are not as expected, the quality of service is declared not ideal ${ }^{1}$.

There are several factors of service quality associated with the level of patient satisfaction known as servqual. Servqual technique helps know the distance between customer expectations and the reality of the customer for the service they receive. In this case, servqual consists of five dimensions of service quality. In addition, this technique can also determine indicators of success in providing health services $^{4}$.

Primary Health Care is a health agency under the auspices of the district/city in charge of developing essential health services. According to the Ministry of Health in 2011, Primary Health Care have service principles, namely promotive, preventive, and curative services. The pro- vided services should be following the provisions set by the Ministry of Health of the Republic of Indonesia ${ }^{5}$.

In Indonesia, certain areas still have low service quality. In terms of facilities, there is a low quality of health workers scientifically and in appearance, health infrastructure facilities, cleanliness of service areas, time management of services. If this still happens within the scope of the health agency, it will undoubtedly reduce the number of visits to the agency ${ }^{6}$.

Primary Health Care is the primary object of this research because the Primary Health Care is the first service agency often used by the community. Supported by various kinds of public perception, the Primary Health Care are only for small groups of people. It was coupled with public health insurance programs provided by the government such as BPJS in making it easier for people in all groups to get economical health services and efficient ${ }^{6}$.

Primary Health Care 1 Melaya, Jembrana-Bali is one of the Primary Health Care that has implemented the Minimum Service Standards (SPM) for Primary Health Care issued by the Ministry of Health of the Republic of Indonesia. This service standard is oriented to total patient satisfaction for health services ${ }^{6}$. Benefits of SPM itself to get a better reputation. Such as increasing awareness of improving service quality, facilitating auditing, improving service quality, increasing customer and employee satisfaction. Furthermore, the hope of using SPM is to support consumer needs following patient expectations.

A comprehensive satisfaction model with the main focus on service goods and services in- 
cludes five dimensions of assessment according to Zeithanel, Berry, and Parasuraman ${ }^{7,8}: 1$ ) Tangible (direct evidence), the availability of good service facilities, and infrastructure. One of them is the cleanliness and tidiness of the service area; 2) Reliability, the expertise of health workers in providing appropriate services; 3) Responsiveness (responsiveness), the speed of service officers in serving patients from registration to receiving health services; 4) Assurance, the ability of officers to provide information about treatment and diagnosis to patients; and 5) Empathy (empathy), health workers are required to build good relationships with patients when providing services. Furthermore, allowing patients to choose their treatment freely is one way for officers to provide empathy.

In determining a high-quality service policy, especially for patients, it is necessary to study the dimensions of the quality of health care services using the servqual technique ${ }^{4}$. The research orientation to be carried out at Primary Health Care 1 Melaya is how much influence this service dimension (Health) has on patient satisfaction ${ }^{4}$.

The orientation carried out in this study is because the researcher wants to know problems such as "is there any influence of reliability, responsiveness, assurance, empathy, tangible variables on patient satisfaction about health services provided by the Primary Health Care? The researcher has known in the initial interview with one of the health workers conducted by researchers in December 2018. The Primary Health Care 1 Melaya will carry out observations and identification and analysis of patient satisfaction. However, the researcher only wanted to know the satisfaction of inpatients at Primary Health Care 1 Melaya on the quality of inpatient services at the Primary Health Care received by patients. So that researchers want to participate in these activities. Currently, the questionnaire made by the Primary Health Care for visiting patients is still the basis of the discourse on the patient satisfaction evaluation program.

Indicators of improving the quality of health services can be seen from the convenience of the community in choosing health care facilities following patient expectations. Improving service facilities both in administration and other practical services can give a good perception of the patient. Apart from the demands written in the legislation, it also determines the loyalty of health service users ${ }^{7}$.

\section{METHOD}

Observational analytic research uses a crosssectional design. The questionnaire as an instrument for collecting data for respondents was modified from Martiana ${ }^{9}$ by reassessing the validity and reliability ${ }^{10}$. The research population used was inpatient visits at Primary Health Care 1 Melaya Jembrana Bali. The sampling method used is purposive sampling, namely sampling using inclusion and exclusion criteria. The sampling technique is total sampling.

Inclusion criteria: able to read and write, Inpatient Polyclinic patients currently receiving health services for at least 2-3 days, and questionnaires will be given to respondents aged between 20-60 years. Patients under 20 years old will be represented by family members aged 30-60 years. Exclusion Criteria: respond- 
ents refuse to be respondents and have physical conditions or have a disease that does not allow them to be respondents.

The independent variables are five dimensions of service that can be identified in terms of infrastructure. The dependent variable is patient satisfaction at Primary Health Care 1 Melaya, Jembrana, Bali, on the quality of service received. The dimensions of service quality are translated into five points (tangibility, reliability, responsiveness, assurance, empathy) which are the basis for assessing the quality of health services. Measurement of service dimensions using a Likert scale (1 = strongly disagree (SD), $2=$ disagree (D), $3=$ quite agree (QA), $4=$ agree (A), $5=$ strongly agree (SA)). Likewise, the dimensions of patient satisfaction were assessed using a Likert scale ( 1 = very dissatisfied (VD), $2=$ dissatisfied (D), 3 = quite satisfied (QS), $4=$ satisfied (S), $5=$ very satisfied (VS)).

Data analysis used multivariate regression analysis with a sample size of 70 respondents ${ }^{11}$. The results of the multivariate regression analysis are written in the form of the following formula:

$Y=a_{0}+\beta_{1} X_{1}+\beta_{2} X_{2}+\beta_{3} X_{3}+\beta_{4} X_{4}+\beta_{5} X_{5}+e$

Description: $Y=$ Patient Satisfaction, $\mathrm{a}_{0}=$ Constant, $\beta_{1-5}=$ Variable Regression Coefficient 15, $\mathrm{X}_{1}=$ Reliability, $\mathrm{X}_{2}=$ Assurance, $\mathrm{X}_{3}=$ Tangible, $\mathrm{X}_{4}=$ Empathy, $\mathrm{X}_{5}=$ Responsiveness, and $\mathrm{e}=$ Standard Error

\section{RESULT}

\section{Patient Characteristics}

Table 1. Patient Characteristics

\begin{tabular}{clcc}
\hline \multicolumn{1}{c}{ Characteristics } & \multicolumn{1}{c}{ Category } & Sum & Percentage \\
\hline \multirow{5}{*}{ Age (year's old, y.o) } & Teneger $(12-25$ y.o) & 20 & $28,6 \%$ \\
& Adult $(26-45$ y.o & 27 & $38,6 \%$ \\
& Elderly $(46-65$ y.o) & 23 & $32,9 \%$ \\
& Senior $(>65$ y.o & 0 & $0,0 \%$ \\
Gender & Male & 24 & $34,3 \%$ \\
& Female & 46 & $65,7 \%$ \\
& Not educated & 2 & $2,9 \%$ \\
& Elementary School & 17 & $24,3 \%$ \\
Education & Yunior Hight School & 7 & $10,0 \%$ \\
& Senior Hight School & 40 & $57,1 \%$ \\
& Diploma & 2 & $2,9 \%$ \\
& Undergraduated & 2 & $2,9 \%$ \\
& Does not work & 13 & $18,6 \%$ \\
& Farmer & 9 & $12,9 \%$ \\
Occupation & Self-employee & 18 & $25,7 \%$ \\
& Housewife & 26 & $37,1 \%$ \\
& Civil servants/mili- & 4 & $5,7 \%$ \\
\hline
\end{tabular}


Based on table 1, the age distribution of patients is evenly distributed among all age categories; $12-25$ y.o, 26-45 y.o, and 46-65 y.o. Moreover, the difference in the most significant number at the age of $26-45$ is $38.6 \%$, adult age-female gender with the most 46 people
(65.7\%). Educated patients were $97.1 \%$, with junior and senior high school education at $67.1 \% .81 .4 \%$ of patients have a permanent job, $25.7 \%$ are self-employed, and $37.1 \%$ are housewives.

\section{Patient Responses Regarding the Quality of Health Services}

Table 2. Tangibility Dimensions of Health Service Quality

\begin{tabular}{|c|c|c|c|c|c|c|c|}
\hline \multirow{2}{*}{ No } & \multirow{2}{*}{ Item } & \multicolumn{5}{|c|}{ Patient Response $(n=70)$} & \multirow{2}{*}{ Means } \\
\hline & & VD & D & QS & $\mathbf{S}$ & VS & \\
\hline 1 & The inpatient room is neat and clean & $0,00 \%$ & $0,00 \%$ & $5,70 \%$ & $78,60 \%$ & $15,70 \%$ & 4,1 \\
\hline 2 & Comfortable inpatient room & $0,00 \%$ & $1,40 \%$ & $8,60 \%$ & $74,30 \%$ & $15,70 \%$ & 4,04 \\
\hline 3 & Have a fairly complete medical equipment & $0,00 \%$ & $7,10 \%$ & $12,90 \%$ & $61,40 \%$ & $18,60 \%$ & 3,91 \\
\hline 4 & Doctor's appearance is clean and neat & $0,00 \%$ & $1,40 \%$ & $7,10 \%$ & $74,30 \%$ & $17,10 \%$ & 4,07 \\
\hline 5 & Nurse appearance is clean and tidy & $0,00 \%$ & $0,00 \%$ & $10,00 \%$ & $71,40 \%$ & $18,60 \%$ & 4,08 \\
\hline 6 & $\begin{array}{l}\text { Wheelchairs/trolleys are available at the recep- } \\
\text { tion office to take patients to the inpatient room }\end{array}$ & $0,00 \%$ & $0,00 \%$ & $0 \%$ & $60,00 \%$ & $0 \%$ & 3,89 \\
\hline 7 & The bed has been prepared neatly & $0,00 \%$ & $1,40 \%$ & $14,30 \%$ & $65,70 \%$ & $18,60 \%$ & 4,01 \\
\hline 8 & $\begin{array}{l}\text { Clean and good eating and drinking utensils } \\
\text { Tangibility Dimensional Service Quality Average }\end{array}$ & $0,00 \%$ & $1,40 \%$ & $15,70 \%$ & $70,00 \%$ & $11,40 \%$ & $\begin{array}{l}3,93 \\
4,01 \\
\end{array}$ \\
\hline
\end{tabular}

On table 2 shows the average value of service quality on the tangibility dimension at Primary Health Care 1 Melaya Jembrana Bali of 4.01. This data shows that patients are satisfied with the quality of service based on physical evidence at the Primary Health Care. The highest average of 4.08 is found in item 5 regarding the appearance of nurses who are considered clean and tidy. While the lowest average value of 3.89 is in the 6th item regarding the availability of wheelchairs to take patients to the inpatient room.

Table 3. Quality of Health Services Dimensions of Reliability

\begin{tabular}{|c|c|c|c|c|c|c|c|}
\hline \multirow{2}{*}{ No } & \multirow{2}{*}{ Item } & \multicolumn{5}{|c|}{ Patient Response $(n=70)$} & \multirow{2}{*}{ Means } \\
\hline & & VD & $\mathbf{D}$ & QS & $\mathbf{S}$ & VS & \\
\hline 1 & $\begin{array}{l}\text { The procedure for receiving patients is served } \\
\text { quickly and without being complicated }\end{array}$ & $0,00 \%$ & $4,30 \%$ & $8,60 \%$ & $74,30 \%$ & $12,90 \%$ & 3,96 \\
\hline 2 & The doctor came on time & $0,00 \%$ & $4,30 \%$ & $14,30 \%$ & $55,70 \%$ & $25,70 \%$ & 4,03 \\
\hline 3 & Doctor's readiness to serve patients & $0,00 \%$ & $1,40 \%$ & $12,90 \%$ & $64,30 \%$ & $21,40 \%$ & 4,06 \\
\hline 4 & Doctors act fast & $0,00 \%$ & $5,70 \%$ & $11,40 \%$ & $58,60 \%$ & $24,30 \%$ & 4,01 \\
\hline 5 & $\begin{array}{l}\text { The readiness of nurses to serve patients at any } \\
\text { time }\end{array}$ & $0,00 \%$ & $4,30 \%$ & $5,70 \%$ & $74,30 \%$ & $15,70 \%$ & 4,01 \\
\hline 6 & $\begin{array}{l}\text { The nurse reports all the details of the patient's } \\
\text { changes to the doctor during the visit }\end{array}$ & $0,00 \%$ & $0,00 \%$ & $11,40 \%$ & $70,00 \%$ & $18,60 \%$ & 4,07 \\
\hline 7 & $\begin{array}{l}\text { The nurse always gives the patient's medication } \\
\text { according to the drug administration procedure }\end{array}$ & $0,00 \%$ & $1,40 \%$ & $11,40 \%$ & $74,30 \%$ & $12,90 \%$ & 3,99 \\
\hline 8 & $\begin{array}{l}\text { The nurse immediately contacted the doctor } \\
\text { about the patient's medicine and food }\end{array}$ & $0,00 \%$ & $2,90 \%$ & $10,00 \%$ & $75,70 \%$ & $11,40 \%$ & 3,96 \\
\hline 9 & $\begin{array}{l}\text { The nurse pays attention to the patient's family } \\
\text { Average Service Quality Dimensions of Reliability }\end{array}$ & $0,00 \%$ & $8,60 \%$ & $11,40 \%$ & $65,70 \%$ & $14,30 \%$ & $\begin{array}{l}3,86 \\
3,99\end{array}$ \\
\hline
\end{tabular}


The average value of service quality on the reliability dimension at Primary Health Care 1 Melaya Jembrana Bali is 3.99, as shown in table 3. This data shows that patients are satisfied with the quality of service based on the reliability of health workers at the Primary Health
Care. The highest average of 4.07 is found in item 6 regarding nurses who report patient changes to doctors during visits. The lowest average value of 3.86 is on the 9th item regarding the nurses' attention to the patient's family, which is lacking.

Table 4. Quality of Health Services Dimensions of Responsiveness

\begin{tabular}{|c|c|c|c|c|c|c|c|}
\hline \multirow[b]{2}{*}{ No } & \multirow[b]{2}{*}{ Item } & \multicolumn{5}{|c|}{ Patient Response $(n=70)$} & \multirow{2}{*}{ Means } \\
\hline & & VD & D & QS & $\mathrm{S}$ & VS & \\
\hline 1 & Doctors always ask the patient's complaints & $0,00 \%$ & $2,90 \%$ & $4,30 \%$ & $80,00 \%$ & $12,90 \%$ & 4,03 \\
\hline 2 & Doctor gives opportunity to ask patient & $0,00 \%$ & $4,30 \%$ & $10,00 \%$ & $70,00 \%$ & $15,70 \%$ & 3,97 \\
\hline 3 & $\begin{array}{l}\text { The doctor gives an explanation about the dis- } \\
\text { ease }\end{array}$ & $0,00 \%$ & $4,30 \%$ & $15,70 \%$ & $71,40 \%$ & $8,60 \%$ & 3,84 \\
\hline 4 & Nurses are friendly and polite & $0,00 \%$ & $1,40 \%$ & $11,40 \%$ & $70,00 \%$ & $17,10 \%$ & 4,03 \\
\hline 5 & $\begin{array}{l}\text { Nurses pay attention to patient needs and com- } \\
\text { plaints }\end{array}$ & $0,00 \%$ & $2,90 \%$ & $8,60 \%$ & $75,70 \%$ & $12,90 \%$ & 3,99 \\
\hline & Average Service Quality Dimensions of Respons & eness & & & & & 3,97 \\
\hline
\end{tabular}

At Primary Health Care 1 Melaya Jembrana Bali, the average value of service quality on the responsiveness dimension is 3.97 , as shown in table 4. This data shows that patients are satisfied with the quality of service based on the responsiveness of health workers at the Primary Health Care. The highest average of 4.03 is found in item number one regarding the attitude of doctors who always ask patients' complaints and item 4 regarding the attitude of nurses who are friendly and polite. The third item has the lowest average score of 3.84, which concerns the doctor's description of the illness, which the patient considers is insufficient.

Table 5. Quality of Health Services Dimensions of Assurance

\begin{tabular}{|c|c|c|c|c|c|c|c|}
\hline \multirow{2}{*}{ No } & \multirow{2}{*}{ Item } & \multicolumn{5}{|c|}{ Patient Response $(n=70)$} & \multirow{2}{*}{ Means } \\
\hline & & VD & $\mathbf{D}$ & QS & $\mathbf{S}$ & VS & \\
\hline 1 & Doctor's behavior creates a sense of security & $0,00 \%$ & $0,00 \%$ & $8,60 \%$ & $74,30 \%$ & $17,10 \%$ & 4,09 \\
\hline 2 & Nurses are educated and able to serve patients & $0,00 \%$ & $2,90 \%$ & $5,70 \%$ & $72,90 \%$ & $18,60 \%$ & 4,07 \\
\hline 3 & Affordable maintenance costs & $0,00 \%$ & $2,90 \%$ & $10,00 \%$ & $72,90 \%$ & $14,30 \%$ & 3,99 \\
\hline 4 & $\begin{array}{l}\text { Maintain patient confidentiality while in the inpa- } \\
\text { tient room }\end{array}$ & $0,00 \%$ & $2,90 \%$ & $7,10 \%$ & $75,70 \%$ & $14,30 \%$ & 4,01 \\
\hline 5 & $\begin{array}{l}\text { Guarantees the patient's recovery } \\
\text { Average Service Quality Dimension Assurance }\end{array}$ & $0,00 \%$ & $4,30 \%$ & $24,30 \%$ & $57,10 \%$ & $14,30 \%$ & $\begin{array}{l}3,81 \\
3,99\end{array}$ \\
\hline
\end{tabular}

The average value of service quality on the assurance dimension at Primary Health Care 1 Melaya, Jembrana Bali is 3.99, as shown in table 5. This data shows that patients are satisfied with the quality of services based on the guarantees provided by medical personnel at the
Primary Health Care. The highest average of 4.09 is found in item number one regarding the behavior of doctors that can create a sense of patient safety. The lowest average value of 3.81 is in the 5th item regarding guarantees for healing patients who are lacking. 
Table 6. Quality of Health Services Dimensions of Empathy

\begin{tabular}{|c|c|c|c|c|c|c|c|}
\hline \multirow{2}{*}{ No } & \multirow{2}{*}{ Item } & \multicolumn{5}{|c|}{ Patient Response $(\mathrm{n}=70)$} & \multirow[b]{2}{*}{ Means } \\
\hline & & VD & D & QS & $\mathrm{S}$ & VS & \\
\hline 1 & Doctor trying to calm the patient's anxiety & $0,00 \%$ & $1,40 \%$ & $11,40 \%$ & $71,40 \%$ & $15,70 \%$ & 4,01 \\
\hline 2 & $\begin{array}{l}\text { Nurses take special time to communicate } \\
\text { with patients }\end{array}$ & $0,00 \%$ & $8,60 \%$ & $7,10 \%$ & $70,00 \%$ & $14,30 \%$ & 3,9 \\
\hline 3 & $\begin{array}{l}\text { Nurses always remind security to keep pa- } \\
\text { tient and family valuables }\end{array}$ & $0,00 \%$ & $10,0 \%$ & $14,30 \%$ & $67,10 \%$ & $8,60 \%$ & 3,74 \\
\hline 4 & $\begin{array}{l}\text { Time to consult the patient's family is ful- } \\
\text { filled }\end{array}$ & $0,00 \%$ & $2,90 \%$ & $14,30 \%$ & $65,70 \%$ & $17,10 \%$ & 3,97 \\
\hline 5 & $\begin{array}{l}\text { Entertaining and encouraging patients to } \\
\text { recover quickly }\end{array}$ & $0,00 \%$ & $2,90 \%$ & $17,10 \%$ & $61,40 \%$ & $18,60 \%$ & 3,96 \\
\hline
\end{tabular}

\section{Instrument Validity and Reliability}

Table 7. Validity and Reliability Test

\begin{tabular}{|c|c|c|c|}
\hline Dimensions & No Item & $\mathrm{r}$ count & Cronbach's Alpha \\
\hline \multirow{8}{*}{ Tangibility } & Item 1 & $\begin{array}{l}0,798^{*} \\
\end{array}$ & \multirow{8}{*}{$0,907 *$} \\
\hline & Item 2 & $0,780^{*}$ & \\
\hline & Item 3 & $0,870^{*}$ & \\
\hline & Item 4 & $0,742^{*}$ & \\
\hline & Item 5 & $0,837 *$ & \\
\hline & Item 6 & $0,703^{*}$ & \\
\hline & Item 7 & $0,792^{*}$ & \\
\hline & Item 8 & $0,709 *$ & \\
\hline \multirow{9}{*}{ Reliability } & Item 1 & 0,593* & \multirow{9}{*}{$0,913^{*}$} \\
\hline & Item 2 & $0,849^{*}$ & \\
\hline & Item 3 & $0,797 *$ & \\
\hline & Item 4 & 0,813* & \\
\hline & Item 5 & $0,808^{*}$ & \\
\hline & Item 6 & $0,738^{*}$ & \\
\hline & Item 7 & $0,771 *$ & \\
\hline & Item 8 & 0,771* & \\
\hline & Item 9 & $0,790^{*}$ & \\
\hline \multirow{5}{*}{ Responsiveness } & Item 1 & 0,819* & \multirow{5}{*}{$0,907 *$} \\
\hline & Item 2 & $0,900^{*}$ & \\
\hline & Item 3 & $0,84)^{*}$ & \\
\hline & Item 4 & $0,797 *$ & \\
\hline & Item 5 & 0,819* & \\
\hline \multirow{5}{*}{ Assurance } & Item 1 & $0,777^{*}$ & \multirow{5}{*}{$0,844^{*}$} \\
\hline & Item 2 & $0,828^{*}$ & \\
\hline & Item 3 & $0,841 *$ & \\
\hline & Item 4 & $0,782^{*}$ & \\
\hline & Item 5 & $0,734^{*}$ & \\
\hline \multirow{5}{*}{ Empathy } & Item 1 & $0,767^{*}$ & \multirow{5}{*}{$0,853^{*}$} \\
\hline & Item 2 & $0,869 *$ & \\
\hline & Item 3 & $0,783^{*}$ & \\
\hline & Item 4 & $0,807^{*}$ & \\
\hline & Item 5 & $0,751 *$ & \\
\hline
\end{tabular}


The average value of service quality on the empathy dimension at Primary Health Care $1 \mathrm{Me}-$ laya Jembrana Bali is 3.92, as shown in table 6 . This data indicates that patients are satisfied with the quality of service based on the attention given by medical personnel at the Primary Health Care. The highest average of 4.01 is found in item 1 regarding doctors who try to calm the patient's anxiety about the illness. The lowest average value of 3.74 is in the 3 rd item regarding the attitude of nurses in reminding the security of the patient's and family's valuables which is felt to be lacking.
The validity and reliability tests in table 7 show the results of all items with the correlation value of $\mathrm{r}$ dimensions of tangibility, reliability, responsiveness, assurance, and empathy above 0.7 , except for item no. 1 in the reliability dimension of 0.593 , so the assessment instrument for all dimensions is categorized as a valid item. At the same time, the value of Cronbach's alpha of all dimensions of tangibility, reliability, responsiveness, assurance, and empathy is more than 0.8 , so that all instrument items are reliable.

\section{The Influence of Service Quality Dimensions on Patient Satisfaction}

Multiple regression tests fulfill normality test, multicollinearity test, heteroscedasticity test, and autocorrelation test. The normality test on the residuals can be done with the Kolmogorov Smirnov test $1.113(p=0.168)$, which states that the data is usually distributed. A good model should not have a high correlation between the independent variables, which can be seen from the tolerance value and variance inflation factor (VIP), the tangible value is 0.884 , respectively; 1.131$)$, reliability $(0.734$;
2.653), responsiveness $(0.912 ; 0.923)$, assurance $(0.821 ; 1.452)$, and empathy $(0.891 ; 1.012)$ which stated that there was no multicollinearity between independent variables.

The data variance does not show a specific pattern, so that it is stated as homoscedasticity, as shown in Figure 1. The Durbin Watson test results obtained a value of 1.765 , located between $-2<1.765<2$, it is concluded that there is no autocorrelation found in the regression model

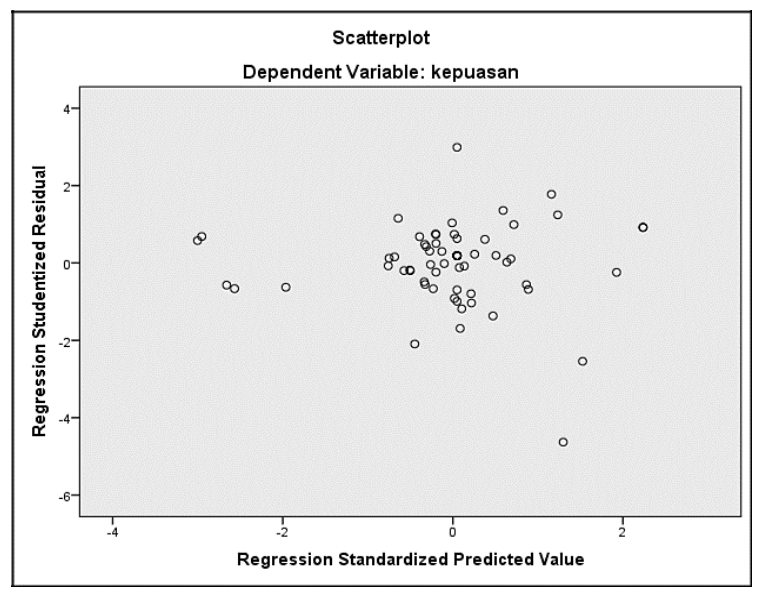

Figure 1. Scatterplot Graph 
Table 8. The Influence of Service Quality Dimensions on Patient Satisfaction

\begin{tabular}{lcccc}
\hline \multicolumn{1}{c}{ Model } & Sum of Square & Mean Square & F & p-value \\
\hline Regression & 11,831 & 2,366 & & \\
Residual & 1,195 & 0,019 & 126,68 & 0,000 \\
Total & 13,027 & & & \\
\hline
\end{tabular}

Table 9. The Influence of Service Quality Dimensions on Patient Satisfaction

\begin{tabular}{lccc}
\hline \multicolumn{1}{c}{ Variable } & Coefficient & $\mathbf{t}$ & $\mathbf{p}$ \\
\hline Constanta & 0,352 & 2,364 & 0,021 \\
Tangibility (X1) & 0,295 & 2,410 & $0,019^{*}$ \\
Reliability (X2) & $-0,104$ & $-0,859$ & 0,394 \\
Responsiveness (X3) & 0,201 & 2,545 & $0,013^{*}$ \\
Assurance (X4) & 0,334 & 2,918 & $0,005^{*}$ \\
Empathy (X5) & 0,180 & 3,304 & $0,002^{*}$ \\
\hline
\end{tabular}

Multiple linear regression analysis results to determine the effect of tangibility, reliability, responsiveness, assurance, and empathy on patient satisfaction consisted of 2 stages, namely simultaneous test ( $F$ test) and partial test $(\mathrm{t}-$ test). The results of the $\mathrm{F}$ test presented in table 8 obtained a significance value of 0.000 (p $<0.05)$, so it can be concluded that simultaneously the service quality variables have a significant effect based on the dimensions of tangibility, reliability, responsiveness, assurance, and empathy to patient satisfaction.

The $\mathrm{t}$-test is used to partially test the regression coefficients of the independent variables, whether each dimension of tangibility, reliability, responsiveness, assurance, and empathy affects patient satisfaction. The dimensions of tangibility, responsiveness, assurance, and empathy in table 9 have a significance value of less than $0.05(p<0.05)$, while the reliability dimension has a significance value of more than 0.05 $(\mathrm{p}>0.05)$. This data shows that the dimensions of tangibility, responsiveness, assurance, and empathy significantly affect patient satisfaction.

So, the formula used to predict patient satisfaction with health services received is as follows:

$\mathrm{y}=0,352+0,295 \mathrm{X} 1-0,104 \mathrm{X} 2-0,201 \mathrm{X} 3$

$+0,334 \times 4+0,180 \times 5$

Following the equation model, the most significant coefficient is indicated by the assurance dimension of 0.334 . This result shows that each increase in the value of service quality on the assurance dimension will increase patient satisfaction by 0.334 .

\section{DISCUSSION}

\section{Instrument Validity and Reliability}

The patient's age distribution is even across all age categories, and the most in the age range 26-45 years by $38.6 \%$, adults-female gender with the most 46 people (65.7\%). Educated patients were $97.1 \%$, with junior and senior high school education at $67.1 \%$. $81.4 \%$ of patients 
have a permanent job, $25.7 \%$ are self-employed, and $37.1 \%$ are housewives. Considering the distribution of patients in the study, patients can understand all the question items in the questionnaire when collecting data ${ }^{10}$. This result is supported by the validity and reliability test findings, which reveal that all items have a correlation value of $\mathrm{r}$ more than 0.7 , except for item number one, which has a reliability dimension of 0.593 , indicating that the assessment instrument is valid. While the value of Cronbach's alpha for all dimensions is more than 0.8 , so all instrument items are reliable.

\section{The Influence of Service Quality Dimensions on Patient Satisfaction}

The quality of health services at Primary Health Care 1 Melaya Jembrana Bali is assessed in five dimensions: tangibility, reliability, responsiveness, assurance, and empathy for patient satisfaction through two stages: simultaneous test ( $\mathrm{F}$ test) and partial test (t-test). The results of the $\mathrm{F}$ test obtained a si-significance value of $0.000(\mathrm{p}<0.05)$, so it can be concluded that simultaneously or simultaneously, the service quality variables are based on the dimensions of tangibility, reliability, responsiveness, assurance, and empathy significantly affect patient's satisfaction.

The results of the t-test show that the dimensions of tangibility, responsiveness, assurance, and empathy have a significance value $(\mathrm{p}<0.05)$, while the reliability dimension has a less significant value $(p>0.05)$. This result shows that the dimensions of tangibility, responsiveness, assurance, and empathy significantly affect patient satisfaction. The most significant coefficient is indicated by the assurance dimension of 0.334 . This condition shows that every increase in service quality value on the assurance dimension will increase patient satisfaction by 0.334 .

\section{Dimension of Tangible}

The tangible dimension has a positive effect on patient satisfaction. More tangible service is more satisfy the patient. Because a service form cannot be seen, cannot be smelled, and cannot be touched, physical appearance becomes essential as a measure of service. At the same time, this aspect is also one of the sources that influence patient expectations. Because with good physical evidence, the patient's expectations are higher. Therefore, hospitals need to know how far the most appropriate physical aspect is, which is still giving a positive impression on the quality of services provided but does not cause patient expectations to be too high to meet patient needs and provide satisfaction to the patient. These results align with Suwuh's research which obtained dimensions of physical evidence $(\mathrm{p}=0.035)$ at the Walantakan Health Center, North Langowan District $^{4}$. Likewise, Panjaitan's research got the reality dimension with a $\mathrm{p}$-value $=0.00313$. The dimensions of physical evidence are also connected with the level of service satisfaction, according to Mariana ${ }^{2}$, Herudiansyah ${ }^{12}$, Puspita ${ }^{13}$, and Dhamawan's research ${ }^{8}$.

\section{Dimensions of Responsiveness}

The responsiveness dimension has a positive effect on patient satisfaction. More responsive service satisfies the patient. One thing that often makes customers disappointed is that patients are often pinged pong when they need information. Passed from one staff to another, the other staff does not know or answer what the patient wants. Unresponsive service and 
will make the patient feel dissatisfied. The responsiveness given by the hospital will increase the satisfaction felt by the patient. These results align with Suwuh's research which found the responsiveness dimension $(p=0.008)$ at the Walantakan Health Center, North Langowan District ${ }^{4}$ Likewise, Panjaitan's research got the responsiveness dimension with a $\mathrm{p}$-value $=$ $0.003^{14}$. The responsiveness dimension is also connected with the level of service satisfaction, according to Mariana ${ }^{2}$, Herudiansyah ${ }^{12}$, Puspita $^{13}$, and Dhamawan ${ }^{8}$.

\section{Dimension of Assurance}

The assurance dimension has a positive effect on patient satisfaction. This result shows that the greater the assurance, the greater the patient satisfaction. Assurance is knowledge of the right product, politeness of employees in providing services, skills in providing information, ability to provide security, and ability to instill trust and confidence in patients in Primary Health Care ${ }^{7}$. According to Patria, what is meant by assurance is the ability to provide the promised service accurately (accurately) and the ability to be trusted (dependably), mainly providing services on time, in the same way, according to the schedule that has been set-promised and without making mistakes every time ${ }^{15}$.

The existence of a security guarantee from a Primary Health Care will make patients feel safe and without any hesitation to seek treatment. Besides that, the guarantee from a Primary Health Care will affect patient satisfaction because what the patient wants can be fulfilled by the Primary Health Care, namely with knowledge and skills from nurses and doctors. Politeness and friendliness of employees will make patients feel valued so that they are satisfied with the services provided by the Primary Health Care. These results align with Suwuh's research which obtained a guarantee dimension $(p=0.036)$ at the Walantakan Health Center, North Langowan District ${ }^{4}$. Likewise, Panjaitan's research obtained the dimension of certainty with a p-value $=0.003^{14}$. Mariana ${ }^{2}$, Herudiansyah $^{12}$, and Puspita ${ }^{13}$, and Dhamawan ${ }^{8}$ have found that the dimensions of security assurance are related to the level of service satisfaction.

\section{Dimension of Empathy}

The empathy dimension has a positive effect on patient satisfaction. More empathy a service more satisfy the patient. Sincere and individual or personal attitudes given by the Primary Health Care to patients such as the ease of contacting the Primary Health Care, the ability of employees to communicate with patients, and the Primary Health Care efforts to understand the wishes and needs of patients From the above understanding, it can be concluded that caring is unique or individual attention to all patient needs and complaints, and good communication between employees and patients. With special attention and good communication from employees to patients, it will also affect patient satisfaction. These results align with Suwuh's research which obtained the dimensions of empathy $(p=0.039)$ at the Walantakan Health Center, North Langowan District $^{4}$. Likewise, Panjaitan's research got the empathy dimension with $\mathrm{p}$-value $=0.003^{14}$ and the results of Mariana's research ${ }^{2}$, Herudiansyah $^{12}$, Dharmawan $^{8}$. In contrast to Puspita's research $^{13}$, the empathy dimension is not correlated with the level of service satisfaction.

\section{Dimensions of Reliability}


Reliability is a dimension that has no significant effect on patient satisfaction. This result shows that patients at Primary Health Care 1 Melaya Jembrana Bali are less concerned about the accuracy of the services. These results are in line with research by Mariana ${ }^{2}$ and Puspita ${ }^{8}$ that the reliability dimension is not correlated with the level of service satisfaction. This result is different from Suwuh's study, which obtained a reliability dimension $(p=0.046)$ at Primary Health Care Walantakan, North Langowan District ${ }^{4}$. Likewise, Panjaitan's research got the reliability dimension with $\mathrm{p}$-value $=0.003^{14}$, Herudiansyah's research at Palembang $\mathrm{Mu}-$ hammadiyah Hospital ${ }^{12}$, and Dharmawan's research $^{8}$.

\section{CONCLUSION}

Service quality based on the dimensions of tangibility, reliability, responsiveness, assurance, and empathy has a significant effect on patient satisfaction at Primary Health Care 1 Melaya Jembrana Bali. The dimension of health service that most influences the satisfaction of inpatients at the Primary Health Care is the dimension of assurance. Patients feel confident and satisfied when health workers communicate their skills and competencies before undertaking service work.

\section{REFERENCE}

1. Kotler \& Keller (dalam Januar \& Ai 2016:266). Pengaruh Kualitas Pelayanan Terhadap Kepuasan Pelanggan Pada Jne Cabang Bandung. DeReMa J Manaj [Internet]. 2016;11(2):25. Available from:

https://ojs.uph.edu/index.php/DJM/ article/view/197
2. Mariana D. Hubungan Kualitas Pelayanan Keperawatan Rawat Inap dengan Proses Pengambilan Keputusan Pasien Untuk Memilih Rumah Sakit. J Ilm Multi Scinece Kesehat [Internet]. 2019;10, No.2(2):145-62. Available from: https://osf.io/4stbx/download

3. Tawalujan TW, Korompis GEC, Maramis FRR. Hubungan Antara Status Akreditasi Puskesmas Dengan Tingkat Kepuasan Pasien Di Kota Manado. Kesmas. 2019;7(5).

4. Suwuh MK, Maramis FRR, Wowor RE, Kesehatan F, Universitas M, Ratulangi $S$, et al. Hubungan Antara Kualitas Jasa Pelayanan Dengan Kepuasan Pasien Di Puskesmas Walantakan Kecamatan Langowan Utara. Kesmas. 2018;7(3):18.

5. Ekasari R, Pradana MS, Adriansyah G, Prasnowo MA, Rodli AF, Hidayat K. Analisis Kualitas Pelayanan Puskesmas Dengan Metode Servqual. J Darussalam J Pendidikan, Komun dan Pemikir Huk Islam. 2017;9(1):82.

6. DINKES. Profil UPT Puskesmas 1 Melaya. Jembrana: Dinkes Kabupaten Jembrana. Jembrana, Bali; 2017.

7. Ridwan I, Saftarina F. Pelayanan Fasilitas Kesehatan: Faktor Kepuasan dan Loyalitas Pasien Healthcare Facility Service: Factors of Satisfaction and Patient Loyalty. Majority. 2015;4(9):206.

8. Dharmawan RH, Kristianingsih T. Pengaruh Kualitas Pelayanan dan Fasilitas Terhadap Kepuasan Pelanggan. J Apl Bisnis. 2018;3(12):120.

9. Martiana. Pengaruh Kualitas Pelayanan Kesehatan Terhadap Kepuasan Pasien Rawat Inap RSUD Cut Meutia Kabupaten Aceh Utara [Internet]. Universitas Sumatera Utara; 2011. Available from: http://repositori.usu.ac.id/handle/123 $456789 / 35340$ 
10. Rohmah LNH, Yuliyanasari N, Ghufron M, Anas M. The Influence of Health Education (Health Promotion) Breast Self Examination (BSE) Against Behavior of BSE (Knowledge, Attitudes, and Action) Student of Madrasah Aliyah Ar-Raudlatul Ilmiyah Islamic Boarding School Kertosono in Early Detection of Brea. In: Proceedings 4th International Conference on Sustainable Innovation (ICoSI) [Internet]. Yogyakarta: UMYPress; 2020. p. 403-7. Available from:

https://icosi.umy.ac.id/2020/publicati on-icosi-2020/

11. Janie DNA. Statistik Deskripstif dan Regresi Linier Berganda dengan SPSS. Stat Deskripstif dan Regresi Linier Berganda dengan SPSS. 2012;52 hal.

12. Herudiansyah G, Candera M, Haminsyah K, Puspita RM, Santoso S. Analisis Pengaruh Kualitas Pelayanan Kesehatan Terhadap Kepuasan Pasien Pada Rumah Sakit Muhammadiyah
Palembang. Jemb (Jurnal Ekon Manajemen, Bisnis, Audit dan Akuntansi). 2018;13(1):69-80.

13. Puspita RM, Santoso S. Pengaruh Kualitas Pelayanan Dan Fasilitas Pendukung Terhadap Kepuasan Pelanggan Stasiun Lempuyangan Yogyakarta. Eksis J Ris Ekon Dan Bisnis. 2018;13(1):69-80.

14. Panjaitan JE, Yuliati AL. Pengaruh Kualitas Pelayanan Terhadap Kepuasan Pelanggan Pada JNE Cabang Bandung [The Influence of Service Quality on Customer Satisfaction at JNE Branch in Bandung]. DeReMa (Development Res Manag J Manaj. 2016;11(2):265.

15. Patria A, Amatiria G. Dimensi Kualitas Layanan terhadap Kepuasan Pasien Rawat Jalan. J Keperawatan [Internet]. 2017;XIII(1):118-25. Available from: https://ejurnal.poltekkestjk.ac.id/index.php/JKEP/article/view /861 